\title{
Program Pendampingan Usaha Mikro Kecil dan Menengah dalam Menyediakan Baju Hazmat di Kota Pekanbaru
}

\author{
Genny Gustina Sari ${ }^{1 *}$, Iwantono ${ }^{2}$, Yohannes Firzal ${ }^{3}$ \\ 1,2,3 Universitas Riau \\ J1. Hr. Soebrantas Km.12,5 Pekanbaru 28293 - Indonesia \\ "Email Korespondensi: genny.gustina@1ecturer.unri.ac.id
}

\begin{abstract}
Abstrak - Wabah Covid-19 yang melanda dunia telah membuat pola hidup berubah. Masyarakat dituntut menjaga jarak sosial, membatasi aktivitas di luar rumah dan menerapkan pola hidup bersih dan sehat. Sisi lain yang menarik untuk dilihat dari pandemi ini adalah tingginya jiwa sosial masyarakat, dibuktikan dengan membantu pihak yang terdampak covid baik kesehatan maupun ekonomi. Salah satu bentuk kepedulian masyarakat adalah membuat dan menyumbangkan masker dan baju hazmat bagi para tenaga medis. Universitas Riau melalui tim Pengabdian kepada Masyarakat (PKM) Covid mencoba memenuhi kebutuhan tersebut melalui pendampingan usaha mikro, kecil, dan menengah (UMKM) di Kota Pekanbaru. Sulitnya menemukan bahan baku pembuatan baju hazmat menyebabkan tim pengabdian harus membeli bahan baku dari luar Pulau Sumatra. Selain itu hanya ada dua UMKM yang bersedia menjahit baju hazmat. Total baju hazmat yang dibuat sebanyak 120 pieces dan telah didistribusikan ke tujuh lokasi di kota Pekanbaru dan sekitarnya.
\end{abstract}

Kata Kunci: Pendampingan, baju hazmat, PKM, covid, UMKM

\section{PENDAHULUAN}

Virus Corona atau Severe Acute Respiratory Syndrome Coronavirus 2 (SARS-CoV-2) adalah virus baru yang menular dari manusia ke manusia dengan menyerang sistem pernapasan. Penyakit ini disebut Covid-19. Virus Corona bisa menyebabkan gangguan ringan pada sistem pernapasan, infeksi paru-paru yang berat, hingga kematian. Virus ini bisa menyerang siapa saja, seperti golongan usia lanjut, orang dewasa, anak-anak, bayi, ibu hamil dan ibu menyusui. World Health Organization menjelaskan, penyebaran virus corona melalui penularan dari orang yang terinfeksi virus corona.

Ketika seseorang yang terinfeksi virus corona bersin dan batuk, maka partikel-partikel virus akan menyebar melalui mulut atau hidungnya. Virus itu mengenai permukaan benda, kemudian disentuh orang sehat tanpa sadar, dan ia memegang hidup ataupun mulutnya sehingga terinfeksi virus. Orang sehat juga terinfeksi setelah terkena droplet (percikan ludah) dari bersin atau batuk orang yang terinfeksi corona (Https://www.cdc.gov/coronavirus/2019ncov/hcp/infection-control.html, 2020).

Hingga 20 Juli 2020 dari data situs Riau Tanggap Corona, di Kota Pekanbaru terdapat 56 orang dalam pengawasan, 28 pasien dalam pemantauan, dan 90 orang positif menderita Covid-19 dengan enam orang pasien meninggal dunia (Corona.riau.go.id diakses pada 20 Juni 2020, https://corona.riau.go.id/, 2020).

Sementara itu, kebutuhan terhadap alat pelindung diri (APD) bagi para tenaga medis sangat tinggi. Namun, pada satu sisi lain, stok APD sangat terbatas dan langka. APD tidak hanya dibutuhkan oleh para tenaga medis, tetapi juga masyarakat. Pengunaan APD sangat mendesak untuk mencegah transmisi Covid-19 dan APD berfungsi sebagai penghalang penularan virus dari pasien ke tenaga kesehatan.

Standarisasi APD penting untuk menjaga keamanan guna menghindari penularan virus. Karena itu material APD harus memenuhi standar tertentu dan terjamin mutunya. Fungsi APD adalah untuk menghindari kontak fisik antara petugas dan pasien agar penyebaran virus dari penderita ke tenaga kesehatan yang menanganinya dapat dihindari (Rohman, 2020:15). 
Pakaian hazardous materials, dikenal juga dengan sebutan baju hazmat atau pakaian dekontaminasi merupakan bagian perlengkapan perlindungan pribadi yang terdiri dari bahan impermeabel untuk proteksi melawan material berbahaya. Baju hazmat umumnya dilengkapi dengan alat bantu pernapasan mandiri untuk memastikan penggunanya mendapat pasokan udara untuk bernafas.

Baju hazmat digunakan oleh petugas pemadam kebakaran, teknisi medis darurat, paramedis, peneliti, petugas yang bereaksi atas kebocoran material berbahaya, tenaga ahli yang membersihkan daerah terkontaminasi, dan pekerja di lingkungan beracun.

Kebutuhan baju hazmat dalam masa pandemi Covid-19 ini semakin mendesak dan karena itu perlu segera dipercepat pengadaannya. Permitaan atas baju hazmat sangat tinggi (Sorta Tobing, 2020).

Fenomena di lapangan menunjukkan ketersediaan baju hazmat di Pekanbaru sangat minim, sehingga ada petugas yang menggunakan baju hazmat tidak sesuai standar yang baik (Putra Dwi, 2020). Untuk itulah dirasa perlu percepatan penyediaan baju hazmat guna didistribusikan bagi para tenaga medis dalam penanganan pasien Covid-19.

Permasalahan umum saat ini adalah langkanya baju hazmat produksi pabrik konveksi. Dalam keterbatasan supply, timbul diupayakan pemenuhannya melalui usaha rumah tangga berskala usaha mikro, kecil, dan menengah (UMKM). Namun usaha rumah tangga memiliki keterbatasan kemampuan produksi dan pengadaan material.

Dari berbagai persoalan tersebut maka diperlukan adanya tim yang dapat mendampingi UMKM dalam memproduksi baju hazmat. Masyarakat yang menjadi sasaran kegiatan pendampingan untuk percepatan pengadaan baju hazmat dalam rangka siaga bancana COVID-19 tersebut adalah UMKM di Pekanbaru yang bergerak di bidang konveksi skala kecil rumahan.

\section{METODE PELAKSANAAN}

Pelaksana penggabdian kepada masyarakat ini terdiri dari tiga orang, diketuai oleh Prof Iwantono dengan anggota tim dua orang yaitu Yohannes Firzal dan Genny Gustina Sari. Tim pelaksana melaksanakan empat garis besar tugas yaitu: (1) kegiatan pra survey lapangan; (2) kegiatan pendampingan UMKM; (3) kegiatan distribusi baju hazmat; dan (4) pembuatan laporan kegiatan (Table 1).

Tabel 1. Pembagian Tugas Tim PKM

\begin{tabular}{|l|l|l|}
\hline \multicolumn{1}{|c|}{ Kegiatan } & \multicolumn{1}{|c|}{ Materi Ipteks } & \multicolumn{1}{c|}{ Penanggung Jawab } \\
\hline Persiapan & Pembuatan proposal kegiatan & $\begin{array}{l}\text { Genny Gustina Sari, } \\
\text { Yohannes Firzal }\end{array}$ \\
\hline Survey Awal & Survey awal kelapangan & $\begin{array}{l}\text { Prof Iwantono, Genny } \\
\text { Gustina Sari, Yohannes } \\
\text { Firzal }\end{array}$ \\
\hline Kegiatan Pendampingan & Pengadaan bahan baju & $\begin{array}{l}\text { Genny Gustina Sari, } \\
\text { Yohannes Firzal }\end{array}$ \\
\hline $\begin{array}{l}\text { Distribusi Hasil } \\
\text { Kegiatan }\end{array}$ & $\begin{array}{l}\text { Pelatihan dan pembekalan para } \\
\text { UMKM }\end{array}$ & $\begin{array}{l}\text { Prof. Iwantono, Genny } \\
\text { Gustina Sari, }\end{array}$ \\
\hline Laporan Kegiatan & $\begin{array}{l}\text { Pendampingan produksi baju } \\
\text { hazmat dan control kualitas }\end{array}$ & $\begin{array}{l}\text { Genny Gustina Sari, } \\
\text { Yohannes Firzal }\end{array}$ \\
\hline
\end{tabular}

Sedangkan rencana teknis pelaksanaan kegiatan dilaksanakan setidaknya 14 kali kunjungan ke lokasi dengan berbagai agenda berbeda. Jadual pelaksanaan tercantum pada Tabel 2;

Tabel 2. Rencana Pertemuan Teknis Lapangan

\begin{tabular}{|l|c|l|l|}
\hline \multicolumn{1}{|c|}{ Jenis Kegiatan/Waktu } & Pertemuan & Lokasi & Pelaksana \\
\hline $\begin{array}{l}\text { Pra survey lapangan } \\
\text { April }\end{array}$ & 2 & Kota Pekanbaru & Tim PKM \\
\hline
\end{tabular}




\begin{tabular}{|l|c|l|l|}
\hline $\begin{array}{l}\text { Kegiatan Pendampingan } \\
\text { (Mei-Juli) }\end{array}$ & 6 & Kampus UNRI & $\begin{array}{l}\text { Genny, } \\
\text { Yohannes, } \\
\text { Majasiswa, } \\
\text { UMKM }\end{array}$ \\
\hline $\begin{array}{l}\text { Distribusi Hasil Kegiatan } \\
\text { (Agustus - Oktober) }\end{array}$ & 4 & Lokasi UMKM & $\begin{array}{l}\text { Tim PkM, } \\
\text { Mahasiswa }\end{array}$ \\
\hline $\begin{array}{l}\text { Pelaporan Kegiatan } \\
\text { (November) }\end{array}$ & 2 & Kampus UNRI & Tim PkM \\
\hline
\end{tabular}

\section{HASIL DAN PEMBAHASAN}

Kegiatan pendampingan bagi UMKM untuk percepatan pengadaan baju hazmat relawan siaga bencana Covid-19, telah melakukan pembinaan dalam pembuatan pakaian baju hazmat yang dilakukan oleh ibu-ibu penjahit di Kota Pekanbaru (Gambar 1). Kegiatan itu sekaligus untuk membantu perekonomian pelaku UMKM di tengah wabah covid-19.

Baju hazmat yang telah selesai dibuat kemudian didistribusikan ke Rumah Sakit dan Klinik dengan tujuan membantu petugas kesehatan seperti dokter, perawat, serta bidan yang harus menangani dan merawat pasien dengan mengenakan APD yang baik sesuai standart.

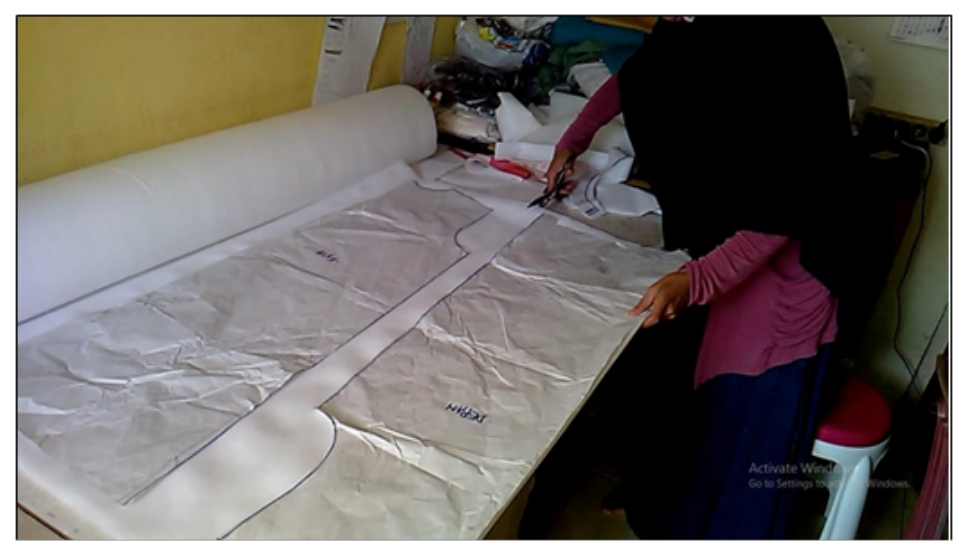

Gambar 1. Proses pembuatan dan pemotongan pola dasar baju hazmat

Kegiatan pembuatan baju hazmat dilakukan di dua tempat, masing-masing tempat menjahit sebanyak 60 baju hazmat untuk didistribusikan ke klinik, rumah sakit, lab dan puskesmas di wilayah Kota Pekanbaru, Provinsi Riau.

Tim menemukan dua UMKM yakni penjahit rumahan yang bekerja secara mandiri dan terkena dampak Covid-19 dari sisi ekonomi. Dua orang penjahit rumahan tersebut berlokasi di Jl. Srikandi dan J1. Garuda Sakti Kota Pekanbaru. Dalam proses produksi baju hazmat, tim PKM berkoordinasi dengan UMKM mengenai model baju, sedangkan bahan dasar pembuatan baju hazmat yakni kain spunbond telah disiapkan oleh tim PKM.

Setelah menyelesaikan program pembuatan baju hazmat, tim kemudian mendistribusikan baju hazmat tersebut ke fasilitas-fasilitas medis yang intens menangani pasien covid-19 dan melayani tes covid-19 baik rapid ataupun swab test (Tabel 3).

Tabel 3. Distribusi Baju Hazmat

\begin{tabular}{|c|l|c|}
\hline No & \multicolumn{1}{|c|}{ Penerima } & Jumlah \\
\hline 1 & RS Pendidikan Universitas Riau & 20 \\
\hline 2 & RS Daerah Madani & 20 \\
\hline 3 & RS Jiwa Tampan & 20 \\
\hline 4 & Lab Biomolekuler RSUD Arifin Ahmad & 10 \\
\hline 5 & Puskesmas Simp Baru Panam & 20 \\
\hline 6 & Puskesmas Poned Sidomulyo & 15 \\
\hline 7 & Puskesmas Sentajo Raya & 15 \\
\hline \multicolumn{2}{|c|}{ Total } & $\mathbf{1 2 0}$ \\
\hline
\end{tabular}




\section{KESIMPULAN}

Kegiatan pengabdian masyarakat dalam rangka peduli Covid 19 telah berhasil dilaksanakan. Kebutuhan Alat Pelindung Diri di lapangan ternyata masih sangat tinggi sementara ketersediaanya di pasaran sangat terbatas. Melalui upaya pemberdayaan UMKM tim pengabdian berhasil membuat dan mendistribusikan 120 buah baju hazmat di kota Pekanbaru.

Dengan adanya kegiatan pendisribusian baju hazmat ini dapat disimpulkan dua hal yakni, pertama, kebutuhan yang tinggi tidak diikuti dengan ketersediaan barang di pasaran. Kalaupun baju hazmat tersedia di pasar, harganya sangat tinggi. Oleh karena itu melalui pembuatan dan pendistrubusian ini diharapkan dapat membantu memenuhi kebutuhan baju hazmat bagi tenaga kesehatan di Pekanbaru. Kedua, melalui pemberdayaan UMKM ini, tim memberikan alternatif bidang usaha baru bagi UMKM yang bergerak di bidang konveksi: selain memproduksi masker, mereka bisa membuat baju hazmat sebagai alternatif usaha.

Dari kegiatan pengabdian ini dapat disimpulkan, perlunya kerjasama dari berbagai pihak dalam membantu pengadaan baju hazmat yang sangat berguna bagi tenaga kesehatan menjalankan tugas mereka menangani pasien Covid-19.

\section{Ucapan Terimakasih}

Tim Pengabdian Masyarakat mengucapkan terimakasih kepada Universitas Riau yang membuka PKM Program Covid-19 sehingga kegiatan ini dapat dilaksanakan. Ucapan terimakasih juga disampaikan kepada para mahasiswa Kuliah Kerja Nyata khusus program Covid serta dua UMKM yang berpartisipasi dalam kegiatan ini.

\section{Daftar Pustaka}

https://corona.riau.go.id/. (2020). Riau tanggap covid-19. Retrieved from https://corona.riau.go.id/

Https://www.cdc.gov/coronavirus/2019-ncov/hcp/infection-control.html. (2020). Infection Control Guidance for Healthcare Professionals about Coronavirus (COVID-19). Retrieved from Centre For Disease Control and Prevention website: https://www.cdc.gov/coronavirus/2019-ncov/hcp/infection-control.html

Putra Dwi, Y. (2020). Mengenal Alat Pelindung Diri (Hazmat Suit) untuk Petugas Kesehatan. Retrieved from Insan Medika website: https://blogs.insanmedika.co.id/mengenal-alatpelindung-diri-hazmat-suit/

Tobing, S. (2020). Panduan Standar APD untuk Tenaga Medis yang Menangani Pandemi Corona. https://katadata.co.id/sortatobing/berita/5e9a41f6148fd/p. Retrieved from https://katadata.co.id/sortatobing/berita/5e9a41f6148fd/panduan-standar-apd-untuktenaga-medis-yang-menangani-pandemi-corona

Rohman, A. et.all (2020. Penggunaan Baju APD untuk Pelindung Covid -19 bagi Tenaga Medis Pada Fasilitas Kesehatan Pratama. Seminar Nasional Terapan Riset Inovatif (SENTRINOV), 6(30, 152-159. 